\title{
Dinamika Dakwah Komunitas Remaja Islam di Kecamatan Pangalengan
}

\author{
Ridwan Rustandi ${ }^{1 *} \&$ Haifa Hanifah ${ }^{2}$ \\ ${ }^{12}$ Universitas Islam Negeri Sunan Gunung Djati, Bandung \\ *Email : ridwanrustandi@uinsgd.ac.id.
}

\begin{abstract}
Teenage age is considered as a vulnerable age because it is experiencing mental turmoil, emotional tension, the process of searching for identity and preparation for physical and mental maturity. For this condition, there are not a few teenagers who are morally integrated and have social values. The presence of an Islamic youth community can be used as a solution to answer various problems of adolescent life. The Islamic youth community in Pangalengan has an agenda and da'wah activities in the context of carrying out guidance and inculcation of Islamic values. This study seeks to analyze various shocks and dynamics of the implementation of da'wah carried out by the Muslim youth community in Pangalengan. The results showed that the existence of an Islamic youth community in Pangalengan could be the answer in carrying out the process of fostering and instilling Islamic values. Generally, this youth community plans sets goals and segments da'wah and implements varied and creative forms of da'wah activities.
\end{abstract}

Keywords : the dynamics of da'wah, muslim youth community, Pangalengan district.

\begin{abstract}
ABSTRAK
Usia remaja dianggap sebagai usia yang rentan karena sedang mengalami kegoncangan jiwa, ketegangan emosi, proses pencarian jatidiri dan persiapan menuju kematangan fisik dan mental. Atas kondisi ini tidak sedikit kalangan remaja yang terdegrasi secara moral dan nilai sosial. Kehadiran komunitas remaja Islam dapat dijadikan sebagai solusi untuk menjawab berbagai problematika kehidupan remaja. Komunitas remaja Islam di Pangalengan memiliki agenda dan kegiatan dakwah dalam rangka melakukan pembinaan dan penanaman nilai-nilai keislaman. Penelitian ini berupaya menganalisis berbagai gejolak dan dinamika pelaksanaan dakwah yang dilakukan oleh komunitas remaja Islam di Pangalengan. Hasil penelitian menunjukkan bahwa eksistensi komunitas remaja Islam di Pangalengan dapat menjadi jawaban dalam melakukan proses pembinaan dan penanaman nilai-nilai keislaman. Umumnya, komunitas remaja ini melakukan perencanaan, penetapan tujuan dan segmentasi dakwah serta pelaksanaan bentuk-bentuk kegiatan dakwah secara variatif dan kreatif.
\end{abstract}

Kata Kunci : dinamika dakwah, komunitas remaja Islam, kecamatan Pangalengan 


\section{PENDAHULUAN}

Upaya untuk mengajak manusia ke jalan keselamatan, ilaa daarissalam, menjadi tanggung jawab setiap muslim yang beriman. Hal ini sebagai karakter utama umat Islam dalam menyeru pada kebaikan (amar maruf) dan mencegah dari keburukan (nabi munkar). Pada hakikatnya, segala bentuk kegiatan yang diorientasikan untuk merubah tatanan pemikiran, perilaku dan perbuatan manusia menuju tata kehidupan berdasar pada ketentuan Islam (syariat) baik dalam lingkup individual maupun sosial lazim dikenal dengan ungkapan dakwah. Dakwah merupakan jalur pendekatan dalam membina kepribadian agar tunduk dan patuh pada ajaran agamanya (Thamrin, 2003: 3).

Orientasi dakwah dalam membentuk pribadi manusia yang bertaqwa bertujuan agar manusia memperoleh kebahagiaan dunia dan akhirat. Terdapat empat tujuan utama dakwah Islam, antara lain: 1) dakwah berorientasi pada dar assalam, yakni upaya membentuk keharmonisan kehidupan di antara sesama umat manusia. Dalam tujuan ini, dakwah Islam hendaknya dilakukan dengan prinsip penebaran semangat rabmatan lil alamin. 2) dakwah dilakukan melalui berbagai dialog dan menghindari perpecahan. Tujuan ini berupaya membangun kesadaran manusia akan pentingnya menjaga literasi keislaman di tengah beragam tantangan global. 3) dakwah dilakukan dengan memerhatikan konsep integral, yakni kajian pemetaan dakwah yang komprehensif baik mengenai subjek dakwah, pesan dakwah, objek dakwah dan pemilihan media dakwah. Sehingga orientasi dakwah tercapai sebagaimana target yang ditetapkan. 4) pelaksanaan dakwah harus mampu menjawab tantangan dan problematika sosial. Output dakwah adalah tertanamnya berbagai aturan Islam dalam kehidupan manusia. Oleh sebab itu, pelaksanaan dakwah harus memperhatikan tingkat relevansi dengan kebutuhan sosial objek dakwah (Muhyiddin dkk, 2014: 28-29).

Dakwah merupakan sebuah aktivitas yang kompleks yang melibatkan berbagai stakeholder dalam komunitas muslim. Kompleksitas dakwah ini ditinjau dari proses transmisi dan transformasi pesan dakwah. Secara praktik, aktivitas dakwah dimulai dari proses perencanaan pesan dakwah, pengiriman oleh da'i, pemilihan media dakwah, penentuan gaya penyampaian pesan dakwah, antisipasi kendala dakwah, penerimaan pesan dakwah oleh madh'u sampai dengan proses pengamalan pesan dakwah dalam kehidupan keseharian. Sehingga, muara dari aktivitas dakwah ini termanifestasikan dalam tatanan pemikiran (frame of refence), perbuatan dan tindakan (behavior) objek dakwah baik dalam skala invidivual maupun masyarakat sebagai sebuah komunitas sosial.

Aktivitas dakwah dilakukan melalui proses perencanaan dan pemetaan medan dakwah. Proses perencaaan dakwah dilakukan agar kegiatan dakwah berlangsung secara sistematis, terukur (measureable), dan dapat dievaluasi. Hal ini dilakukan agar aktivitas dakwah Islam dapat dilakukan secara profesional, efektif 
dan efisien. Oleh sebab itu, proses perencanaan dakwah dilakukan dengan memperhatikan tujuan utama dari dakwah Islam, kompleksitas kegiatan dan capaian target yang ditetapkan. Tentunya, proses perencanaan ini disesuaikan dengan ruang lingkup dakwah Islam dilakukan sesuai dengan medan dakwah yang menjadi objek aktivitas dakwah. Berdasarkan konteksnya, perencanaan dan pelaksanaan aktifitas dakwah dapat dilakukan baik secara nafsiab (dakwah kepada diri sendiri), fardiyah (dakwah kepada satu orang), fi'ah (dakwah kelompok kecil), hizbiyah (dakwah kelompok besar), ummah (dakwah dengan tidak bertatap muka, khalayak yang banyak), dan syu'ubiyah wa qobailiyah (dakwah lintas budaya) (Aripudin \& Sambas, 2012: 18).

Keberagaman objek dakwah yang ditinjau dari latar belakang geografi (wilayah), pendidikan, ekonomi, sosial dan budaya menjadi tantangan bagi para subjek dakwah dalam proses mentransmisikan ajaran Islam. Oleh sebab itu, kajian dan pemetaan medan dakwah menjadi penting dilakukan agar proses menyeru dan mengajak manusia ke jalan Tuhan (sabili robbika) dapat dilakukan sesuai dengan kebutuhan objek dakwah. Pada titik ini, apabila dakwah dilakukan sesuai dengan kebutuhan dan kondisi madh'u, maka akan tercapai tatanan kehidupan sebagaimana yang digambarkan Allah Swt dalam al-qur'an. Yakni, kehidupan manusia yang hayatan thoyyibatan dan baldatun thoyyibatun baik pada level individual maupun komunitas sosial.

Segmentasi dakwah yang beragam (multikultural) adalah sebuah realitas objek dakwah yang tidak dapat dihindari. Bagi para subjek dakwah, segmentasi ini merupakan medan dakwah yang harus disentuh dan dibina sesuai dengan ketentuan pelaksanaan dakwah Islam. Oleh sebab itu, pada proses praktiknya, penyampaian pesan-pesan keislaman dilakukan dengan memperhatikan kondisi dan kebutuhan dari setiap segmentasi madh'u. Segmentasi madh'u dapat dikategorikan berdasarkan tingkat kuantitas dan kualitasnya. Misalnya, kegiatan dakwah dengan objek perseorangan, kelompok kecil, kelompok besar, khalayak ramai dan komunitas berbeda suku dan budaya. Tingkatan kuantitas tersebut didasarkan pada banyaknya objek dakwah yang dicapai. Sementara tingkatan kualitas objek dakwah dapat dilihat dari sisi perbedaan tingkat pendidikan, latar belakang sosial-budaya (pedesaan dan perkotaan), taraf hidup ekonomi dan perbedaan preferensi politik.

Perbedaan segmentasi objek dakwah di atas, memunculkan adanya dinamika dalam proses perencanaan dan pelaksanaan dakwah. Dinamika dakwah ini berlangsung dari sisi bentuk kegiatan dakwah yang dilakukan, proses capaian kegiatan dakwah dan kendala-kendala dari pelaksanaan dakwah yang terjadi. Dinamika dakwah ini sebagai bukti beratnya tanggung jawab pelaksanaan dakwah yang dilakukan oleh setiap muslim. Mengingat bahwa dakwah Islam adalah upaya menebarkan spirit Islam rabmatan lil alamin yang harus menyentuh berbagai individu, komunitas dan masyarakat sebagai objek dakwah. 
Salah satu daerah yang dipandang memiliki tingkat aktivisme yang besar dalam kegiatan dakwah Islam adalah Kecamatan Pangalengan yang berada pada cakupan geografi Kabupaten Bandung Provinsi Jawa Barat. Kecamatan Pangalengan merupakan salah satu daerah di Kabupaten Bandung dengan luas wilayah mencapai 195, $41 \mathrm{KM}$ persegi. Dengan luas geografi tersebut, Pangalengan menempati urutan kedua sebagai kecamatan terluas di Kabupaten Bandung setelah Kecamatan Rancabali. Pada tahun 2017, jumlah penduduk di Kecamatan Pangalengan sekitar 153.102 ribu jiwa dengan komposisi penduduk laki-laki sebesar 76.798 ribu jiwa dan perempuan sebesar 76.304 ribu jiwa. Secara administratif, di Kecamatan Pangalengan terdapat 13 desa terdiri dari desa Wanasuka, Banjarsari, Margaluyu, Sukaluyu, Warnasari, Pulosari, Margamekar, Sukamanah, Margamukti, Pangalengan, Margamulya, Tribaktimulya dan Lamajang. Secara umum, kondisi topografis Pangalengan merupakan daerah pegunungan dan perbukitan dengan ketinggian di atas permukaan laut bervariasi antara 984 m sampai dengan $1.571 \mathrm{~m}$ (BPS Kabupaten Bandung, 2018).

Berdasarkan kelompok umur, jumlah penduduk di Kecamatan Pangalengan terdiri dari kelompok umur 0-14 tahun berjumlah 48.544 jiwa, umur 15-64 tahun berjumlah 96.935 jiwa dan umur 65 tahun ke atas berjumlah 7.623 jiwa. Adapun jumlah remaja usia sekolah berdasarkan tingkatan pendidikan dari mulai SMP/MTs, SMA/SMK/MA dan Santri Pondok Pesantren di Pangalengan berjumlah 11.414 orang. Berdasarkan latar belakang pendidikan, lulusan SD/sederajat berjumlah 58.400 jiwa, lulusan SLTP/sederajat berjumlah 31.008 jiwa, lulusan SLTA/sederajat berjumlah 15.187 jiwa, lulusan D1/D2/D3 berjumlah 1.558 jiwa dan lulusan D4/S1/S2/S3 berjumlah 1.628 jiwa. Sementara itu, jumlah institusi pendidikan baik $\mathrm{SD} /$ sederajat, SLTP/sederajat dan SMA/sederajat berturut-turut sebanyak 76, 17 dan 10 unit sekolah. Adapun jumlah lembaga pendidikan Islam terdiri dari 10 unit pondok pesantren dan 128 madrasah diniyah (BPS Kabupaten Bandung, 2018).

Secara sosial dan agama, masyarakat di Kecamatan Pangalengan merupakan masyarakat multikultural. Berdasarkan kategori agama, jumlah tempat peribadatan umat beragama terdiri dari 308 masjid, 298 langgar/surau/mushola dan 2 gereja. Dengan jumlah tersebut, menunjukkan bahwa mayoritas masyarakat di Kecamatan Pangalengan beragama Islam. Selain itu, dari sudut keberadaan pelaku dakwah secara administrative jumlah Penyuluh Agama Islam sebanyak 7 orang, mubaligh sebanyak 88 orang dan khotib sebanyak 131 orang. Sedangkan dari latar belakang sosial, tercatat bahwa permasalahan kesejahteraan sosial terdiri dari masyarakat yang cacat mental dan fisik, gelandangan dan pengemis, anak terlantar, anak jalanan, tuna Susila, bekas narapidana dan korban NAPZA. Adapun dari sisi kegiatan ekonomi, secara umum mata pencaharian masyarakat Pangalengan mayoritas dari sektor pertanian (perkebunan dan peternakan), perdagangan, industri kecil dan menengah serta jasa/buruh pabrik, pertanian dan pertambangan 
(BPS Kabupaten Bandung, 2018).

Data di atas menunjukkan bagaimana tingkat kompleksitas kegiatan dakwah yang dilakukan di Kecamatan Pangalengan. Hal ini merujuk pada kondisi objektif baik secara geografis, kultural, ekonomi dan sosiologis yang ada di Kecamatan Pangalengan. Oleh sebab itu, fokus penelitian ini diarahkan pada aktifitas dakwah yang menyebabkan berbagai dinamika yang dilakukan pada objek dakwah dengan segmentasi remaja. Masa remaja adalah masa transisi dari anak-anak menuju dewasa. Pada masa remaja sedang dirundung ego yang tinggi, masa dimana rasa keingintahuan yang cukup besar sehingga jika tidak tertanam hal positif pada diri mereka, maka berbagai hal negatif ingin mereka coba, sehingga membutuhkan bimbingan dan arahan (Nawawi, 2018: 121). Berdasarkan kategori umur yang dikeluarkan Departemen Kesehatan RI (2009), kelompok umur remaja terdiri dari masa remaja awal yang berumur antara 12-16 tahun dan masa remaja akhir 17-25 tahun (Al-amin \& Juniati, 2017).

Sementara itu, komunitas berasal dari bahasa latin communitas yang memiliki arti kesamaan lalu diturunkan menjadi communis yang memiliki arti sama. Pada sebuah komunitas ditemukan hal yang utama yaitu kesamaan dan identitas. Selain itu dalam komunitas terdapat partisipasi dan saling berbagi (sharing). Terbentuknya komunitas karena memiliki kepentingan yang sama atau disebut dengan community of interest (Nawawi, 2017). Komunitas merupakan sebutan pada sekelompok masyarakat yang memiliki karakteristik, kemudian mereka berkumpul di suatu wilayah tertentu dengan batasan-batasan tertentu. Adapun faktor utama yang melatarbelakangi perkumpulannya yakni adanya interaksi yang lebih besar dibanding dengan masyarakat lainnya, sehingga masyarakat ini akan terlihat berbeda dibandingkan masyarakat umum lainnya (Soekanto, 2013:18). Dalam hal ini, komunitas yang dimaksud oleh peneliti adalah sebuah perkumpulan remaja dengan tujuan tertentu berdasarkan ciri, karakteristik dan kesamaan kepentingan yang dimiliki. Komunitas remaja ini adalah sebuah perkumpulan remaja Islam yang memiliki tujuan melaksanakan dakwah Islam. Dengan begitu, komunitas remaja yang dijadikan objek penelitian adalah komunitas-komunitas remaja di Pangalengan yang dipandang aktif melaksanakan syiar Islam dengan berbagai metode dan bentuknya.

Berdasarkan pengamatan peneliti, setidaknya terdapat 13 komunitas remaja Islam yang berada di Kecamatan Pangalengan. Antara lain Komunitas Dakwah Pangalengan (KOMDAPA), Majelis Remaja dan Pelajar Islam (MERAPI), Hammock Tafakkur, Malam Minggu Ngaji (MMN), Kalam Media, Ikatan Remaja Studi Islam Intensif (IRSIF), Remaja Ukhuwah Nurul Yaqin (REUNY), Bobotoh Taqwa Pangalengan, Forum Remaja Islam Ishlahul Amanah (FRIIA), Ikatan Remaja Masjid Al-Falah (IRMAFAL), Ikatan Remaja Masjid Al-Muthmainnah (IREMA) SMANSA Pangalengan, Forum Silaturahmi Remaja Masjid Al-Muttaqin (FORSIREMA), dan Syubbanul Firdaus. Ketigabelas komunitas remaja Islam ini 
tersebar di 13 desa di wilayah kecamatan Pangalengan. Dalam pengamatan penulis, ketigabelas komunitas ini melakukan aktivitas dakwah baik secara konvensional (melalui mimbar, kajian rutin dan diskusi) maupun dengan menggunakan media baru (internet) dalam bentuk representasi kegiatan dakwah melalui akun media sosial, channel youtube, dan lain-lain. Dengan demikian, keberadaan 13 komunitas remaja Islam ini dipandang merepsesentasikan aktivitas dakwah remaja di kecamatan Pangalengan.

Merujuk pada data Badan Pusat Statistik (BPS) Kabupaten Bandung tahun 2017, jumlah penduduk usia remaja yang dihitung berdasarkan tingkatan pendidikan pada rentang usia 12-14 tahun (usia SMP) dan rentang usia 15-18 tahun (usia SMA) berjumlah 11.414 orang. Jumlah tersebut didapatkan dari data BPS mengenai jumlah siswa SMP, MTs, SMA, SMK dan MA serta jumlah santri dari pondok pesantren. Adapun rincian jumlah tersebut terdiri dari 1.022 santri dari pondok pesantren, 4.878 siswa SMP, 1.776 siswa MTs, 1.571 siswa SMA, 1.776 siswa SMK dan 394 siswa MA. Dengan begitu, dapat dikatakan bahwa target atau sasaran objek dakwah komunitas remaja Islam di Pangalengan secara kuantitas berjumlah 11.414 orang remaja dengan rentang usia 12-14 tahun berjumlah 6.654 orang dan rentang usia 15-18 tahun berjumlah 3.738 orang. Sisanya 1.022 adalah santri dari pondok pesantren dengan rentang usia 12-25 tahun.

Penelitian sebelumnya berkaitan dengan dinamika dakwah komunitas remaja pernah dilakukan oleh Susanto (2014) mengenai Pola Strategi Dakwah Komunitas Habaib di Kampung Melayu Semarang. Riset ini menunjukkan bahwa strategi dakwah yang dilakukan komunitas Habaib di Semarang dilakukan dengan memperhatikan kondisi sosiologi dan psikologi madh'u. Salah satu strategi yang dilakukan adalah melalui tradisi lisan yang tumbuh dan berkembang secara turuntemurun. Riset Syukur (2014) mengenai Dinamika Dakwah Dalam Komunikasi dan Penyiaran Islam; Pendekatan Historisasi, Formulasi dan Aplikasi. Hasil riset menujukkan bahwa pendekatan multidisipliner dapat dikembangkan oleh perguruan tinggi dalam menjawab berbagai problematika dan tantangan dakwah kontemporer. Problematika dan tantangan dakwah tersebut terutama berkaitan dengan perkembangan teknologi dan ilmu pengetahuan. Oleh karena itu, kajian teoritik yang bersifat normatif dan aplikatif harus dilakukan untuk menjawab berbagai dinamika dakwah hari ini. Riset Putrawan (2018) mengenai konsep Sekolah Perjumpaan sebagai Gerakan Dakwah Berbasis Komunitas. Hasil riset menunjukkan bahwa integrasi nilai-nilai ajaran Islam di sekolah formal dipandang kurang berhasil dalam proses transmisi dan pelaksanaan dakwah Islam. Oleh sebab itu, Gerakan Sekolah Perjumpaan yang di gagas di sejumlah desa di Kabupaten Lombok Barat mampu menjadi alternatif solusi dalam menanamkan nilai-nilai ajaran Islam. Kegiatan ini dipandang mampu meningkatkan kualitas keberagamaan objek dakwah.

Riset Ginda (2018) mengenai Dinamika Dakwah Islam dalam Perspektif 
Manajemen Perubahan di Kecamatan Tampan. Hasil penelitian menyimpulkan bahwa majelis taklim sebagai salah satu lembaga dakwah memiliki peran signifikan dalam proses transmisi ajaran Islam. Dinamika dakwah yang terjadi salah satunya dapat dijawab dengan memfungsikan secara maksimal keberadaan majelis taklim. Beberapa kelemahan yang dimiliki majelis taklim dalam perspektif manajemen perubahan terdapat pada struktur lembaga, visi-misi-orientasi, skill SDM dan rencana kerja majelis taklim yang belum sistematis, terukur dan terevaluasi. Riset Nurjanah dan Fatoni (2019) mengenai Dakwah Kelompok pada Komunitas Pejuang Mahar. Hasil riset menyimpulkan bahwa dakwah kelompok pada komunitas ini dilakukan melalui berbagai pendekatan dengan orientasi yang bersifat motivasional dan komunikatif. Selain itu, komunitas Pejuang Mahar berorientasi pada proses menjawab problematika remaja berkaitan dengan isu pacaran.

Riset di atas menunjukkan bagaimana pentingnya melakukan kajian mengenai dinamika kegiatan dakwah yang dilakukan oleh umat Islam. Dinamika tersebut baik yang terjadi di wilayah geografi pedesaan maupun perkotaan. Kajiannya pun cukup beragam baik berkaitan dengan penelitian mengenai objek tertentu yang memfokuskan sebagai komunitas dakwah dengan isu yang tertentu, kajian kelembagaan majelis taklim sebagai sebuah komunitas dakwah, kegiatan atau event dakwah tertentu sebagai konsep yang berbasis dakwah komunitas, maupun kajian dinamika dakwah dengan sudut pandang manajemen perubahan.

Merujuk pada penelitian-penelitian di atas, maka penelitian ini difokuskan pada upaya untuk menggali berbagai bentuk dinamika dakwah yang dilakukan oleh beberapa komunitas remaja Islam di Kecamatan Pangalengan. Dinamika dakwah tersebut baik berupa bentuk kegiatan dakwah, proses perencanaan dan penetapan objek dakwah dan proses evaluasi dari capaian dakwah yang dilakukan. Penelitian menggunakan pendekatan kualitatif dengan metode studi kasus. Pendekatan kualitatif digunakan untuk melihat, merekam, mencermati dan menghayati berbagai fenomena dari objek kajian. Bagaimana kegiatan dakwah dilakukan, penetapan tujuan dan segmentasi dakwah, bentuk-bentuk kegiatan dakwah dan evaluasi capaian dakwah. Sedangkan metode studi kasus dilakukan untuk menggambarkan berbagai gejala berkaitan dengan dinamika aktifitas dakwah yang dilakukan oleh 13 komunitas dakwah remaja Islam di Kecamatan Pangalengan. Adapun beberapa fenomena yang diteliti meliputi kegiatan dakwah rutinan, eventual-seremonial, dan variasi-variasi aktifitas dakwah yang direncanakan oleh komunitas dakwah remaja di Pangalengan.

\section{HASIL DAN PEMBAHASAN}

\section{Kondisi Objektif dan Pemetaan Komunitas Dakwah Remaja Islam}

Perubahan sosial adalah sebuah konsekuensi dari proses perkembangan 
masyarakat. Hal ini didasarkan pada beberapa aspek antara lain berkaitan dengan tingkat kompleksitas kebutuhan manusia, perkembangan teknologi dan ilmu pengetahuan, modernitas zaman dan faktor perubahan individu. Dinamika masyarakat berubah seiring dengan perkembangan struktur sosial-fungsional dalam masyarakat itu sendiri. Sehingga, perubahan sosial menghendaki adanya perubahan individu sekaligus proses modernisasi dan globalisasi baik dari sisi pemikiran, mentalitas dan perubahan fisik.

Agama dalam literatur sosiologi diperhitungkan sebagai salah satu faktor yang menyebabkan terjadinya perubahan sosial di masyarakat. Institusi sosial agama seperti gereja, masjid, sinagog, organisasi masyarakat Islam, dan lain-lain dalam konteks masyarakat kekinian tidak hanya berfungsi menyediakan layanan spiritual bagi jemaatnya, tetapi juga terlibat aktif dalam penyelesaian persoalan masyarakat sekitar. Agama secara teoretis dapat mendorong perubahan sosial sekaligus dapat berfungsi sebaliknya, yakni menghambat perubahan sosial. Hal ini disebabkan nilai-nilai agama menjadi pandangan hidup yang membimbing perilaku manusia (Haryanto, 2015: 232-234).

Agama dapat bersifat ekstensif dalam arti menarik banyak pihak terlepas ruang dan waktu, tetapi dapat pula bersifat intensif yang memungkinkan kontrol terhadap pemahaman dan perilaku. Agama merupakan elemen ideologis yang paling kuat (powerful) di setiap masyarakat. Orientasi agama membantu masyarakat mendefinisikan sesuatu itu "baik" atau "buruk" dan mengarahkan tindakan kolektif (Sherkat, 2006: 7-8).

Kedudukan agama dalam kehidupan masyarakat dapat menjadi faktor pendorong (enabler) terjadinya perubahan sosial maupun faktor penghambat (constraint) dari perubahan sosial yang terjadi. Agama sebagai enabler berasumsi bahwa kekuatan nilai keyakinan dan moralitas agama berimplikasi terhadap perilaku ekonomi, perubahan politik dan proses modernisasi dalam kehidupan masyarakat. Dalam hal ini, agama memiliki peran signifikan dalam merubah tatanan pemikiran, mental dan moral penganutnya agar memiliki daya perubahan dalam kehidupan sosial. Sedangkan agama sebagai constraint terjadi ketika nilai-nilai yang terkandung dalam agama tidak mampu merespons situasi yang berubah. Hal ini terjadi karena dalam sebagian besar penganut agama berpandangan bahwa nilai-nilai agama tidak sesuai dengan konteks perubahan ruang dan waktu sebagai dampak adanya modernitas (Haryanto, 2015: 240-244).

Agama dalam pandangan Toffler mengalami perubahan seiring dengan tingkat kemajuan atau peradaban masyarakat. Pandangan seperti ini mengisyaratkan perubahan penilaian terhadap fungsi agama pada masyarakat modern. Perspektif terkini mengenai agama menyatakan bahwa agama sebagai sistem simbol kognitif, afektif, dan evaluatif menjadi basis pilihan evaluatif masyarakat, tidak hanya pilihannya dalam arah tujuan hidup, tetapi juga dalam merespons terhadap situasi yang terjadi di masyarakat sekitar. Durkheim 
menyatakan peran penting agama khususnya dalam menjamin tatanan moral, integrasi sosial, dan identitas personal. Perspektif sosiologi agama dalam melihat hubungan antara modernitas dan agama secara umum dapat dibedakan menjadi dua, yakni persepektif pesimistik dan perspektif optimistik (Haryanto, 2015: 250).

Pandangan pesimistik menilai bahwa modernitas sebagai ancaman serius bagi eksistensi agama. Sedangkan pandangan optimistik menilai bahwa modernitas bukan sebagai alasan untuk absennya agama, melainkan sebagai momentum untuk meramaikan kehadiran agama yang memiliki kemampuan adaptif dalam merespon setiap perubahan sosial yang terjadi. Dalam hal ini, Islam sebagai agama memiliki pengaruh kuat dalam merespon berbagai fenomena dan perubahan sosial yang terjadi. Pandangan keduanya (pesimistik maupun optimistik) dapat terjadi dalam kondisi internal umat Islam. Hal ini akan sangat tergantung pada kerangka pikir umat Islam dalam memosisikan perubahan. Dengan kata lain, setiap agama, termasuk Islam memiliki respon yang berbeda terhadap modernitas.

Pandangan di atas, dapat dijadikan sebagai rujukan untuk menganalisis berbagai dinamika aktivitas dakwah yang terjadi di Pangalengan. Dinamika sosial yang berkaitan dengan agama mengandung sebuah konsekuensi dari perubahan yang terjadi. Apakah agama dalam hal ini menjadi faktor pendorong terjadinya sebuah dinamika sosial atau sebaliknya menjadi faktor penghambat kemajuan masyarakat?

Observasi peneliti menyimpulkan bahwa eksistensi komunitas dakwah remaja Islam di Pangalengan menjadi salah satu bukti adanya keterkaitan nilai-nilai agama Islam dengan proses perubahan masyarakat. Segala bentuk aktivitas dakwah remaja Islam di Pangalengan dapat digambarkan sebagai salah satu upaya dalam merespon berbagai perubahan sosial yang terjadi. Setidaknya terdapat 13 komunitas remaja Islam di Kecamatan Pangalengan yang memfokuskan pada kegiatan dakwah sebagai salah satu alternatif solusi dalam melakukan proses pembinaan dan penanaman nilai-nilai moral ajaran Islam di kalangan remaja. Ketigabelas komunitas dakwah remaja Islam ini melakukan berbagai varian kegiatan dan aktivitas dakwah sesuai dengan segmentasi dan sasaran objek dakwahnya. Rata-rata kegiatan dakwah dilakukan dalam beberapa format kegiatan, dimana segmentasi madh'u-nya adalah remaja yang berada pada rentang usia 1225 tahun.

Aktivitas dakwah dilakukan melalui proses perencanaan dan pemetaan medan dakwah. Proses perencaaan dakwah dilakukan agar kegiatan dakwah berlangsung secara sistematis, terukur, dan dapat dievaluasi. Hal ini dilakukan agar aktivitas dakwah Islam dapat dilakukan secara profesional, efektif dan efisien. Proses perencanaan dakwah dilakukan dengan memperhatikan tujuan utama dari dakwah Islam, kompleksitas kegiatan dan capaian target yang ditetapkan.

Berikut peneliti gambarkan data komunitas dakwah remaja Islam di Kecamatan Pangalengan dalam tabel berikut: 
Tabel 1.

Data Identitas Komunitas Remaja Islam di Kecamatan Pangalengan

\begin{tabular}{|c|c|c|c|c|c|c|c|}
\hline No & $\begin{array}{l}\text { Nama } \\
\text { Komunitas }\end{array}$ & $\begin{array}{l}\text { Tahun } \\
\text { Berdiri }\end{array}$ & Alamat & Pembina & Ketua & $\begin{array}{l}\text { Jml } \\
\text { Angg }\end{array}$ & $\begin{array}{l}\text { Rentang } \\
\text { Usia }\end{array}$ \\
\hline 1 & $\begin{array}{l}\text { Ikatan Remaja } \\
\text { Masjid Al- } \\
\text { Falah } \\
\text { (IRMAFAL) }\end{array}$ & 1995 & $\begin{array}{l}\text { Desa } \\
\text { Margamukti }\end{array}$ & $\begin{array}{l}\text { Jajat } \\
\text { Ruhiat } \\
\text { Asep } \\
\text { Sopandi }\end{array}$ & $\begin{array}{l}\text { Mualif } \\
\text { Assidiq }\end{array}$ & $\begin{array}{l}35 \\
\text { orang }\end{array}$ & $\begin{array}{l}10 \\
\text { orang } \\
(12-14 \\
\text { tahun) } \\
15 \\
\text { orang } \\
(15-25 \\
\text { tahun) }\end{array}$ \\
\hline 2 & $\begin{array}{l}\text { Majelis Remaja } \\
\text { dan Pelajar } \\
\text { Islam } \\
\text { (MERAPI) }\end{array}$ & 2013 & $\begin{array}{l}\text { Desa } \\
\text { Pangalengan }\end{array}$ & $\begin{array}{l}\text { Anwar } \\
\text { Sanusi } \\
\text { Ridwan } \\
\text { Rustandi }\end{array}$ & $\begin{array}{l}\text { Yugi } \\
\text { Habibi }\end{array}$ & $\begin{array}{l}50 \\
\text { orang }\end{array}$ & $\begin{array}{l}20 \\
\text { orang } \\
(12-14 \\
\text { tahun) } \\
30 \\
\text { orang } \\
\text { (15-25 } \\
\text { tahun) }\end{array}$ \\
\hline 3 & $\begin{array}{l}\text { Malam Minggu } \\
\text { Ngaji (MMN) }\end{array}$ & 2017 & $\begin{array}{l}\text { Desa } \\
\text { Margamukti }\end{array}$ & $\begin{array}{l}\text { Ridwan } \\
\text { Rustandi }\end{array}$ & $\begin{array}{l}\text { Redha } \\
\text { Ramadhan }\end{array}$ & $\begin{array}{l}15 \\
\text { orang }\end{array}$ & $\begin{array}{l}15-25 \\
\text { tahun }\end{array}$ \\
\hline 4 & $\begin{array}{l}\text { Hammock } \\
\text { Tafakkur }\end{array}$ & 2016 & $\begin{array}{l}\text { Desa } \\
\text { Margamukti }\end{array}$ & $\begin{array}{l}\text { Ridwan } \\
\text { Rustandi }\end{array}$ & $\begin{array}{l}\text { Irfan } \\
\text { Sovian } \\
\text { Chaidir }\end{array}$ & $\begin{array}{l}10 \\
\text { orang }\end{array}$ & $\begin{array}{l}15-25 \\
\text { tahun }\end{array}$ \\
\hline 5 & $\begin{array}{l}\text { Komunitas } \\
\text { Dakwah } \\
\text { Pangalengan } \\
\text { (KOMDAPA) }\end{array}$ & 2018 & $\begin{array}{l}\text { Desa } \\
\text { Margamukti }\end{array}$ & $\begin{array}{l}\text { Anwar } \\
\text { Sanusi } \\
\text { Hanafi } \\
\text { Anshory } \\
\text { Ridwan } \\
\text { Rustandi }\end{array}$ & $\begin{array}{l}\text { Tursiwa } \\
\text { Nugraha }\end{array}$ & $\begin{array}{l}50 \\
\text { orang }\end{array}$ & $\begin{array}{l}20 \\
\text { orang } \\
(12-14 \\
\text { tahun) } \\
30 \\
\text { orang } \\
(15-25 \\
\text { tahun) }\end{array}$ \\
\hline 6 & $\begin{array}{l}\text { Bobotoh } \\
\text { Taqwa } \\
\text { Pangalengan }\end{array}$ & 2018 & $\begin{array}{l}\text { Desa } \\
\text { Pangalengan }\end{array}$ & - & $\begin{array}{l}\text { Andi } \\
\text { Zulfiqri }\end{array}$ & $\begin{array}{l}10 \\
\text { orang }\end{array}$ & $\begin{array}{l}15-25 \\
\text { tahun }\end{array}$ \\
\hline
\end{tabular}

Sumber : Observasi 2020 
Tabel 1.

Data Identitas Komunitas Remaja Islam di Kecamatan Pangalengan

\begin{tabular}{|c|c|c|c|c|c|c|c|}
\hline 7 & $\begin{array}{l}\text { Remaja } \\
\text { Ukhuwah } \\
\text { Nurul Yaqin } \\
\text { (REUNY) }\end{array}$ & 2006 & $\begin{array}{l}\text { Desa } \\
\text { Mrgamukti }\end{array}$ & $\begin{array}{l}\text { Dindin } \\
\text { Ahmad } \\
\text { Tohidin }\end{array}$ & $\begin{array}{l}\text { Irfan } \\
\text { Salman }\end{array}$ & $\begin{array}{l}24 \\
\text { orang }\end{array}$ & $\begin{array}{l}5 \text { orang } \\
\text { (12-14 } \\
\text { tahun) } \\
19 \text { orang } \\
\text { (15-25 } \\
\text { tahun) }\end{array}$ \\
\hline 8 & $\begin{array}{l}\text { Ikatan Remaja } \\
\text { Studi Islam } \\
\text { Intensif } \\
\text { (IRSIF) }\end{array}$ & 2010 & $\begin{array}{l}\text { Desa } \\
\text { Margamukti }\end{array}$ & $\begin{array}{l}\text { Hanafi } \\
\text { Anshory } \\
\text { Rexy } \\
\text { Abdullah }\end{array}$ & $\begin{array}{l}\text { M. Iqbal } \\
\text { Mubarok }\end{array}$ & $\begin{array}{l}15 \\
\text { orang }\end{array}$ & $\begin{array}{l}5 \text { orang } \\
(12-14 \\
\text { tahun) } \\
10 \text { orang } \\
\text { (15-25 } \\
\text { tahun) }\end{array}$ \\
\hline 9 & $\begin{array}{l}\text { Forum Remaja } \\
\text { Islam Ishlahul } \\
\text { Amanah } \\
\text { (FRIIA) }\end{array}$ & 2018 & $\begin{array}{l}\text { Desa } \\
\text { Margamukti }\end{array}$ & $\begin{array}{l}\text { Ridwan } \\
\text { Rustandi }\end{array}$ & $\begin{array}{l}\text { Nandang } \\
\text { Sutisna }\end{array}$ & $\begin{array}{l}20 \\
\text { orang }\end{array}$ & $\begin{array}{l}15-18 \\
\text { tahun }\end{array}$ \\
\hline 10 & $\begin{array}{l}\text { Klub Aksara } \\
\text { Literasi Isla, } \\
\text { Ishlahul } \\
\text { Amanah } \\
\text { (KALAM) }\end{array}$ & 2018 & $\begin{array}{l}\text { Desa } \\
\text { Margamukti }\end{array}$ & $\begin{array}{l}\text { Ridwan } \\
\text { Rustandi }\end{array}$ & $\begin{array}{l}\text { Ilham } \\
\text { Nashrullah }\end{array}$ & $\begin{array}{l}20 \\
\text { orang }\end{array}$ & $\begin{array}{l}16-18 \\
\text { tahun }\end{array}$ \\
\hline 11 & $\begin{array}{l}\text { Ikatan Remaja } \\
\text { Masjid Al- } \\
\text { Muthmainnah } \\
\text { (IREMA) } \\
\text { SMAN 1 } \\
\text { Pangalengan }\end{array}$ & 2015 & $\begin{array}{l}\text { Desa } \\
\text { Margamulya }\end{array}$ & $\begin{array}{l}\text { Asep } \\
\text { Istiqlal }\end{array}$ & Radian & $\begin{array}{l}40 \\
\text { orang }\end{array}$ & $\begin{array}{l}15-17 \\
\text { tahun }\end{array}$ \\
\hline 12 & $\begin{array}{l}\text { Forum } \\
\text { Silaturahmi } \\
\text { Remaja Masjid } \\
\text { Al-Muttaqin } \\
\text { (FORSIREMA) }\end{array}$ & & $\begin{array}{l}\text { Desa } \\
\text { Pangalengan }\end{array}$ & $\begin{array}{l}\text { Hanafi } \\
\text { Anshory }\end{array}$ & $\begin{array}{l}\text { Fikri Rizki } \\
\text { Fauzi }\end{array}$ & $\begin{array}{l}25 \\
\text { orang }\end{array}$ & $\begin{array}{l}3 \text { orang } \\
(12-14 \\
\text { tahun) } \\
22 \text { orang } \\
\text { (15-25 } \\
\text { tahun) }\end{array}$ \\
\hline 13 & $\begin{array}{l}\text { Syubbanul } \\
\text { Firdaus }\end{array}$ & & $\begin{array}{l}\text { Desa } \\
\text { Pulosari }\end{array}$ & $\begin{array}{l}\text { Hanafi } \\
\text { Anshory }\end{array}$ & & $\begin{array}{l}20 \\
\text { orang }\end{array}$ & $\begin{array}{l}20 \text { orang } \\
\text { (18-21 } \\
\text { tahun) }\end{array}$ \\
\hline
\end{tabular}

Sumber : Observasi 2020

Tabel 1 di atas menunjukkan peta sebaran komunitas remaja Islam di Kecamatan Pangalengan berdasarkan wilayah geografi dan segmentasi umur 
anggota. Berdasarkan tabel di atas disimpulkan bahwa dari 13 komunitas remaja Islam yang aktif melaksanakan kegiatan dakwah di Pangalengan, 8 komunitas berada di desa Margamukti, 3 komunitas di desa Pangalengan, 1 komunitas di desa Margamulya dan 1 komunitas di desa Pulosari. Sementara itu, rentang usia anggota dominan berada pada rentang usia remaja akhir 15-25 tahun. Afiliasi kegiatan komunitas terdiri dari 4 komunitas (FRIAA, KALAM, IREMA dan Syubbanul Firdaus) berada di bawah binaan institusi Pendidikan formal, 4 komunitas (IRMAFAL, IRSIF, REUNY dan FORSIREMA) merupakan komunitas binaan masjid jami pada lingkungan setempat, dan 5 komunitas (MERAPI, KOMDAPA, MMN, BOTAQ Pangalengan dan Hammock Tafakkur) merupakan komunitas yang dibentuk tanpa afiliasi pada masjid dan lembaga pendidikan formal tertentu.

Eksistensi komunitas dakwah remaja Islam di Pangalengan ini semakin berkembang memasuki dekade 2000-an. Apalagi momentum pada kurun 20152020 semakin menunjukkan geliat aktivisme dakwah Islam bagi kalangan remaja di Pangalengan. Hal ini ditandai dengan berbagai helatan kegiatan dakwah baik dalam bentuk dakwah billisan, bilqalam maupuna bilhal. Semaraknya aktivitas dakwah Islam di kalangan remaja Pangalengan salah satunya dipicu dengan masuk dan meresapnya berbagai informasi yang tersebar melalui media internet. Salah satunya ditandai dengan geliat "hijrah" yang terjadi di beberapa kota besar, terutama kota Bandung. Kemunculan geraka hijrah yang diinisiasi oleh "Pemuda Hijrah" di kota Bandung dengan konsep dan konten kreatif yang disebarkan melalui media internet memengaruhi pola pikir, pola perilaku dan strategi dakwah komunitas remaja Islam di Pangalengan. Penggunaan media sosial seperti Facebook, Instagram dan kanal Youtube oleh beberapa komunitas dakwah di Kota Bandung dengan mudah diterima oleh beberapa aktivis dakwah di Pangalengan. Sehingga, memberikan stimulus dan alternatif dalam memetakan pendekatan dan pelaksanaan proses dakwah Islam.

Merujuk pada data Badan Pusat Statistik (BPS) Kabupaten Bandung tahun 2017, jumlah penduduk usia remaja yang dihitung berdasarkan tingkatan pendidikan pada rentang usia 12-14 tahun (usia SMP) dan rentang usia 15-18 tahun (usia SMA) berjumlah 11.414 orang. Jumlah tersebut didapatkan dari data BPS mengenai jumlah siswa SMP, MTs, SMA, SMK dan MA serta jumlah santri dari pondok pesantren. Adapun rincian jumlah tersebut terdiri dari 1.022 santri dari pondok pesantren, 4.878 siswa SMP, 1.776 siswa MTs, 1.571 siswa SMA, 1.776 siswa SMK dan 394 siswa MA. Dengan begitu, dapat dikatakan bahwa target atau sasaran objek dakwah komunitas remaja Islam di Pangalengan secara kuantitas berjumlah 11.414 orang remaja dengan rentang usia 12-14 tahun berjumlah 6.654 orang dan rentang usia 15-18 tahun berjumlah 3.738 orang. Sisanya 1.022 adalah santri dari pondok pesantren dengan rentang usia 12-25 tahun. Sementara itu, jumlah penggerak komunitas dakwah remaja Islam di Pangalengan berdasarkan data keanggotaan dari 13 komunitas remaja Islam di atas berjumlah 334 orang. 


\section{Problematika Dakwah Remaja di Kecamatan Pangalengan}

Masa remaja adalah masa transisi dari anak-anak menuju dewasa. Masa remaja ditandai dengan adanya perkembangan psikologis dalam tahap pubertasi. Hal ini dapat dilihat dari adanya perubahan bentuk fisik, volume suara, stabilitas mental, proses idolaisasi, dan lain-lain. Masa remaja adalah masa peralihan, masa kegoncangan jiwa, masa dirundung oleh egositas diri yang tinggi dan masa menuju proses pematangan mental dan fisik.

Ada lima perubahan yang dialami seseorang di usia remaja dan ini hampir bersifat universal. Pertama, perubahan meningginya emosi yang intensitasnya bergantung pada tingkat perubahan fisik dan psikologis; Kedua, perubahan tubuh; Ketiga, perubahan minat dan peran yang diharapkan oleh kelompok sosial yang dipesankan, menimbulkan masalah baru bagi remaja. Dan ini akan mengakibatkan remaja akan merasa dilimbuni permasalahan sampai ia sendiri mampu menyelesaikan menurut kepuasannya; Keempat, pada usia anak-anak dianggap penting pada periode remaja tidak lagi dianggap penting; dan Kelima, mayoritas remaja bersikap ambivalen terhadap setiap perubahan. Artinya mereka menuntut kebebasan akan tetapi mereka enggan atau meragukan kesanggupan untuk bertanggung jawab (Rachmiatie, Sidik, \& Farihat, 2004: 134).

Implikasi perubahan tersebut terjadi pada beberapa aspek dalam diri remaja, antara lain pertama, masa remaja sebagai masa bermasalah. Hal ini ditandai dengan adanya asumsi bahwa remaja adalah masa pubertas dan penyesuaian terhadap beberapa kondisi perubahan. Sehingga, tidak sedikit remaja yang mengalami gejolak jiwa yang ujungnya melakukan kenakalan bahkan pada tingkatan kriminal. Kedua, stabilitas emosi. Secara fisiologis dan biologis, masa remaja adalah masa ketegangan emosi. Hal ini ditandai dengan adanya perubahan fisik dan bekerjanya kelenjar-kelenjar pada usia remaja. Ketiga, identitas. Masa remaja adalah masa pencarian jati diri. Proses identifikasi kelompok sosial dan mencari acuan sesuai dengan idolanya adalah fase wajar pada usia remaja. Dalam hal identitas, setiap orang pada masa remaja berupaya menegaskan jati dirinya mengikuti kelompok sosial dan idola yang menjadi rujukan (reference group dan member group). Kelima, pola pikir. Masa remaja adalah masa dimana pola pikir remaja bersifat subjektif, dimana ia memandang kehidupan berdasarkan kacamatanya bukan berdasarkan sebagaimana adanya. Oleh sebab itu, masa remaja cenderung memiliki pola pikir yang tidak realistic, mengawang dan subjektif. Kelima, kesiapan mental. Masa peralihan menuju kedewasaan menyebabkan sebagian besar remaja ingin dipandang sebagai manusia yang siap menjelang dewasa. Hal ini ditandai dengan identifikasi dan pembuktian sikap yang dipandang dewasa. Beberapa remaja menujukkan sikap dewasanya melalui perilaku merokok, meminum minuman keras, perbuatan seks, penggunaan obat-obatan, dan lain-lain. Sebagian lagi mengalami proses alienasi dari lingkungan sekitarnya. Masa kesiapan mental adalah kondisi gelisah dan kegoncangan jiwa remaja. 
Berdasarkan hasil penelitian, beberapa problematika dakwah yang dialami oleh komunitas remaja Islam di Pangalengan antara lain:

Pertama, ancaman penyimpangan aqidah Islam karena adanya gerakan sesat dan menyesatkan. Hal ini diakui oleh informan bahwa di kecamatan Pangalengan terdapat beberapa organisasi yang dikategorikan sebagai organisasi sesat dan menyesatkan. Selain itu, berdasarkan historisnya, pengakuan informan menyatakan bahwa pada dekade 2000-an di daerah Pangalengan pernah menjadi target gerakan kristenisasi.

Kedua, pergaulan bebas remaja seperti merokok, pacaran, meminum khamr, kelompok bermotor berperilaku negatif (vandalisme), dan lain-lain. Hal ini diakui informan bahwa salah satu tujuan dibentuknya komunitas dakwah remaja adalah untuk mengcounter kebiasaan dan pergaulan remaja yang dianggap di luar batas kewajaran. Selain itu, terdapat beberapa kasus kehamilan di luar nikah yang pernah terjadi di beberapa remaja di Pangalengan.

Ketiga, kurangnya literasi keislaman dan rendahnya minat dalam mengkaji dan memahami ajaran Islam. Diakui oleh informan, keberadaan komunitas remaja Islam masih belum diminati secara merata oleh beberapa kalangan remaja. Hal ini menyebabkan pada aspek pemahaman dan pengamalan ajaran Islam masih didapati remaja yang belum seutuhnya menjalankan kewajiban agama. Misalnya, dalam beberapa kesempatan peneliti pernah mendapati sekelompok muda-mudi yang masih abai dalam melaksanakan kewajiban sholat. Atas dasar tersebut, informan menyatakan bahwa motivasi menggerakkan komunitas dakwah remaja di Pangalengan adalah untuk melakukan pembinaan dan gerakan penyadaran mengenai hal-hal pokok dalam aspek ibadah. Selain itu, penguasaan keilmuan terhadap landasan atau pedoman pokok beragama seperti tafsir qur'an, kitab hadits, ilmu nahwu, dan lain-lain menjadi problem literasi keislaman yang dihadapi oleh komunitas remaja Islam di Pangalengan.

Keempat, ancaman globalisasi dalam bentuk sebaran informasi dan kontenkonten negatif dari internet. Hal ini diakui oleh informan bahwa kecanggihan teknologi apabila tidak diiringi oleh upaya membentengi fondasi keimanan remaja akan mendatangkan bencana dan kegoncangan jiwa remaja. Informan menyatakan bahwa tidak sedikit para remaja yang mengkonsumsi konten-konten negatif dalam bentuk pornografi, tindak kekerasan, kenakalan yber, termasuk kecanduan games. Pada akhirnya, sebagian besar komunitas dakwah remaja di Pangalengan berupaya memanfaatkan internet sebagai media dakwah untuk mengcounter infiltrasi kontenkonten negatif bagi remaja.

Kelima, hilangnya identitas keislaman di kalangan remaja. Hal ini diakui informan melalui beberapa budaya tasyabuh yang dilakukan oleh kalangan remaja. Misalnya, peneliti pernah mendapati beberapa remaja yang berpakaian dengan mode tertentu, gaya rambut, perilaku hedonisme dan perbuatan-perbuatan lainnya yang dalam pandangan informan dan peneliti bukan bagian dari budaya 
masyarakat Pangalengan. Selain itu, derasnya informasi yang masuk melalui media internet semakin mempermudah perilaku imitasi yang dilakukan oleh remaja di Pangalengan dan dipandang jauh dari nilai-nilai ajaran Islam.

Beberapa problematika dakwah remaja di atas beriringan dengan semakin pesatnya teknologi informasi dan komunikasi sebagai wujud artifisial modernitas. Di era globalisasi, dinamika dakwah di kalangan remaja dihadapkan dengan kemunculan berbagai perangkat teknologi yang canggih. Faktanya, sebagian besar objek dakwah komunitas remaja Islam di Pangalengan adalah remaja yang berada pada rentang usia 15-25 tahun. Dimana para remaja ini memiliki relasi yang intim dengan perangkat teknologi seperti internet, gadget, media sosial, dan lain-lain. Oleh karenanya, problematika remaja yang tampak adalah pada saat keaktifan madh'u dalam menggunakan perangkat teknologi tersebut. Misalnya, internet sebagai media komunikasi baru menyebabkan terjadinya pergeseran pola dan cara interaksi dan komunikasi manusia. Internet secara positif menyebabkan bias geografis dalam cakupan ruang dan waktu. Internet mengintegrasikan manusia dengan manusia lainnya, manusia dengan kelompok sosialnya, dan manusia dengan kebutuhannya. Abad informasi menghendaki adanya pertukaran pesan, gagasan, nilai dan tanda dalam sebuah sistem informasi yang berjejaring, efektif dan berlangsung secara berkelanjutan (Rustandi, 2019: 88).

Dengan demikian, era globalisasi memberikan pengaruh signifikan terhadap remaja dalam proses perkembangan dan pertumbuhannya. Hal ini ditandai dengan serangkaian sikap dan karakter dari para remaja yang terpengaruh oleh kemunculan perangkat-perangkat komunikasi baru. Pada gilirannya, perangkat komunikasi ini merubah tatanan interaksi baik secara structural maupun kultural. Secara tidak langsung, proses pergeseran interaksi ini mempengaruhi pola pikir, mentalitas dan sikap dari para remaja.

\section{Proses Perencanaan dan Penetapan Tujuan Dakwah Komunitas Remaja Islam}

Rosulullah Saw adalah teladan utama bagi seluruh umat Islam dalam menyampaikan risalah Islam. Dalam beberapa kesempatan Rosulullah Saw selalu mendakwahkan Islam sesuai dengan konteks dan kebutuhan. Manajemen dakwah yang dilakukan oleh Rosulullah Saw berpedoman pada kitab dakwah utama yakni al-qur'an yang mengajarkan bagaimana pentingnya melakukan amar maruf dan nabi munkar dengan memperhatikan segmentasi dan kebutuhan objek dakwah (madh'u). Teladan dakwah yang Rosulullah Saw lakukan sangat variatif. Rosulullah selalu memperhatikan kondisi objeknya, latar sosial, tingkat pengetahuan dan kecakapan, status ekonomi, termasuk dalam hal pengembangan strategi (siyasab) atau politik dakwahnya. Hal ini dilakukan agar risalah yang disampaikan menyerap pada hati objeknya, sehingga mau menerima dan mengamalkannya (Rustandi \& Sahidin, 2019: 364). 
Secara umum, dengan merujuk surat An-nahl ayat 125 para ahli mengklasifikasikan metode dakwah Rosulullah ke dalam tiga kategori, yakni: metode hikmah, manidzah hasanah dan mujadalah. Implementasi ketiga metode dakwah di atas, dilakukan melalui berbagai forum, cara dan media variatif sesuai dengan segmentasi dan kebutuhan madh'u. Derivasi metode dakwah tersebut dilakukan misalnya melalui lembaga pendidikan, lembaga dakwah, lembaga keuangan, lembaga sosial, ormas Islam, partai politik, dan lembaga lainnya. Ini menunjukkan bagaimana dakwah dapat dilakukan melalui proses pelembagaan yang dapat menopang nilai-nilai pengetahuan, keterampilan, mentalitas dan sikap atau tindakan seseorang agar berkesesuaian dengan nilai-nilai Islam. Selain itu, bermekarannya cara dan media dakwah lainnya seperti majelis taklim, forum ilmiah Islami, study club, pelatihan da'i (tambidul mubalighin), dialog interaktif, debat, maupun melalui teknik dan forum negosiasi atau perundingan (Rustandi \& Sahidin, 2019: 365). Pada prinsipnya, proses perencanaan dan penetapan tujuan dakwah komunitas remaja Islam di Pangalengan dilakukan ke dalam tiga tahapan, yakni, pembinaan, pengamalan dan pengajaran. Ketiga tahapan ini diterjemahkan ke dalam beberapa variasi kegiatan dakwah dengan orientasi menjawab berbagai tantangan dan problematika dakwah remaja di Pangalengan.

Alur perencanaan dan penetapan tujuan dakwah komunitas remaja Islam di Pangalengan dapat digambarkan pada bagan di bawah ini:

\section{Bagan 1.}

Alur Proses Perencanaan dan Penetapan Tujuan Dakwah Komunitas Remaja Islam di Pangalengan

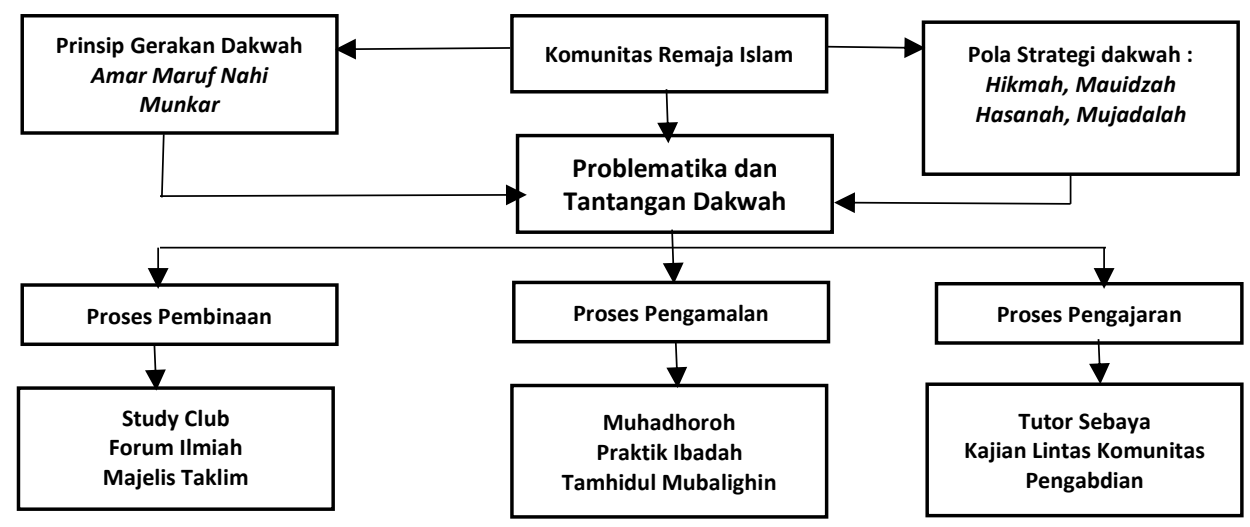

Tujuan: Terbinanya Remaja Islam yang berakhlaq Karimah

Sumber : Observasi 2019 
Bagan 1 di atas menggambarkan alur perencanaan dan penetapan tujuan dakwah dalam proses kegiatan dakwah komunitas remaja Islam di Pangalengan. Proses pembinaan dilakukan melalui kegiatan rutinan yang langsung diisi oleh para pembina. Variasi kegiatan pembinaan dilakukan sesuai dengan kebutuhan anggota di setiap komunitas remaja Islam. Biasanya pembinaan meliputi aspek aqidah dan mentalitas, dalil-dalil praktik ibadah, keterampilan keorganisasian, dan penguatan fikrah keislaman. Pembinaan dilakukan dalam bentuk kajian (mubahatsah), forum ilmiah, study club dan lain-lain. Pembinaan dilakukan secara berkala dan berkesinambungan. Sebagian besar komunitas remaja Islam menjadwalkan kegiatan pembinaan selama satu kali dalam seminggu.

Selanjutnya, proses pengamalan adalah praktik dan pembiasaan nilai-nilai dan ajaran agama Islam dalam kehidupan keseharian. Proses latihan pengamalan dilakukan dalam bentuk praktik ibadah, mubadhoroh atau praktik berpidato, kursus mubaligh, dan lain-lain. Selain itu, pembina melakukan pengawasan dalam proses pembiasaan nilai-nilai ajaran Islam yang di dapat di komunitas berkaitan dengan amalan yaumiyyah anggota komunitas. Sedangkan, tahap pengajaran dilakukan sebagai upaya pembelajaran untuk menyampaikan kembali pelajaran-pelajaran keagamaan yang di dapat selama aktif dan terlibat dalam kegiatan dakwah komunitas. Proses pengajaran dilakukan dalam dua bentuk yakni pengajaran di internal komunitas dengan menjadi tutor sebaya bagi anggota lainnya, dan pengajaran di eksternal komunitas ketika melakukan silaturahmi dan kajian Bersama dengan komunitas lainnya atau melakukan praktik dan pengabdian dakwah di masyarakat sekitarnya.

Muara dari proses perencanaan dan penetapan tujuan dakwah komunitas remaja Islam ini berdasarkan pengakuan informan adalah untuk menjawab problematika remaja di Pangalengan. Hal ini terutama berkaitan dengan proses pembinaan akhlaq dan pengamalan praktik ibadah. Secara variatif komunitas remaja Islam di Pangalengan melaksanakan kegiatan dakwah dengan membaca trend, minat dan kesukaan objek dakwah di kalangan remaja. Selain itu, komunitas remaja Islam di Pangalengan juga secara kreatif memanfaatkan media internet yang akrab dengan keseharian remaja sebagai media dakwah. Berdasarkan observasi penulis dari 13 komunitas remaja Islam di Pangalengan, yang aktif melakukan dakwah di media internet antara lain MERAPI, KOMDAPA, Hammock Tafakkur, IREMA, IRSIF, REUNY, IRMAFAL, MMN, FRIAA, FORSIREMA dan KALAM. Media dakwah komunitas di internet ini biasanya tersebar dalam bentuk akun media sosial facebook, instagram dan whatsapps group.

\section{Bentuk Kegiatan Dakwah Komunitas Remaja Islam}

Aktifitas dakwah merupakan upaya transformatif dalam menyebarkan risalah 
Ridwan Rustandi \& Haifa Hanifah

Islam. Secara fundamental, dakwah Islam diorientasikan kepada upaya-upaya perwujudan umat Islam (manusia) yang lebih baik (Khoiruddin, 2012). Secara garis besar paling tidak bentuk dakwah ada tiga, yakni: dakwah lisan (dakwah billisan), dakwah tulis (dakwah bilqalam), dan dakwah tindakan (dakwah bilhal). Ketiga bentuk kegiatan dakwah ini merujuk pada teladan dakwah transformative Rosulullah Saw berdasarkan surat An-nahl ayat 125 (Zaini, 2017: 259).

Pertama, dakwah billisan dapat diartikan sebagai proses penyampaian ajaran islam melalui ceramah dan komunikasi antar da'i dan madh'u. Kedua, dakwah bilqalam ialah proses kegiatan menyampaikan ajaran islam melalui tulisan, seperti buku, novel, dan lain-lain. dakwah ini memiliki kelebihan dan keunikan yakni tidak dibatasi ruang dan waktu, dapat dibaca kapan dan dimana saja, terutama tulisan yang dimuat dalam internet dapat dijangkau lebih banyak orang. Ketiga, dakwah bilhal ialah proses mengajak dalam kebaikan dengan bentuk amal, kerjanyata, seperti misalnya membangun lembaga pendidikan Islam dan melakukan kerjabakti. Dakwah bilhal banyak menekankan pada masalah kemasyarakatan seperti kemiskinan, kebodohan dan keterbelakangan dengan wujud amal nyata terhadap sasaran dakwah (Aziz, 2009: 359).

Eksistensi gerakan dakwah komunitas remaja Islam di Pangalengan berdasarkan bentuknya dapat dikategorikan sebagai berikut:

Pertama, kategori bentuk kegiatan dakwah berdasarkan tempat pelaksanaan kegiatan. Hal ini ditinjau dari penggunaan sarana dan fasilitas kegiatan dakwah yang dilakukan oleh komunitas dakwah remaja Islam di Pangalengan secara variatif. Misalnya, sebagian besar komunitas dakwah remaja Islam di Pangalengan menggunakan masjid sebagai pusat kegiatan dakwah dan pusat-pusat kajian. Beberapa masjid yang dijadikan sebagai basecamp kegiatan dakwah misalnya, masjid Nurul Yaqin, Urwatul Wutsqa, Al-Huda, Al-Muttaqien, Al-Muthmainnah, Arraudhoh, Firdaus, Al-falah, dan masjid Kaum Pangalengan. Masjid-masjid tersebut umumnya digunakan sebagai pusat kegiatan utama pelaksanaan dakwah komunitas remaja Islam baik dalam bentuk dakwah billisan, bilqalam, maupun bilhal.

Selain masjid, ruang-ruang publik digunakan pula sebagai sarana pelaksanaan kegiatan dakwah komunitas remaja Islam di Pangalengan dalam beberapa kategori kegiatan dakwah yang bersifat eventual atau seremonial. Misalnya, penggunaan aula pemerintahan desa (kantor desa), auditorium sekolah atau madrasah, aula pondok pesantren, dan beberapa kegiatan dakwah bilhal yang dilaksanakan di bale RW, terminal kendaraan, wahana wisata (situ cileunca, taman pinus, kampung rahong, ruing gunung, dan lain-lain) serta beberapa pusat keramaian di Pangalengan.

Kedua, kategori bentuk kegiatan dakwah berdasarkan fokus isu kajian dakwah. Terdapat beberapa isu pokok, misalnya komunitas MERAPI memiliki 3 program unggulan dalam bentuk Ahad Bermanfaat, Ahad Qiraat dan Ahad Khidmat. Fokus isunya berkaitan dengan pemanfaatan waktu luang untuk kegiatan 
positif dalam bentuk pembinaan akhlaq remaja. Komunitas IRSIF memiliki 3 program unggulan kegiatan dakwah yakni Majelis Malam Rabu, Majelis Tarbiyatunnisa dan Halaqah Malam Sabtu. Komunitas ini selain memberikan pembinaan akhlaq juga berupaya meningkatan kecakapan remaja dalam memahami sumber-sumber normatifitas ajaran Islam. Komunitas Malam Minggu Ngaji (MMN) memiliki fokus kajian dakwah dalam penanganan pergaulan remaja mengenai pacarana. Kegiatan dilaksanakan setiap malam minggu untuk mengalihkan masa pubertas remaja terhadap lawan jenis dengan mengalihkan waktu malam minggu untuk kegiatan keagamaan.

Komunitas Hammock Tafakkur memiliki fokus isu kegiatan dakwah dalam bentuk pengajian atau taklim di alam terbuka. Komunitas ini memiliki gerakan dakwah dengan upaya memanfaatkan minat dan keterampilan remaja dalam berekreasi dengan menyisipi kegiatan-kegiatan keagamaan. Komunitas Hammock Taffakur biasanya melakukan kegiatan ekspedisi dan pengajian di alam terbuka. Komunitas REUNY membekali anggotanya dengan keterampilan dalam penguasaan bahasa arab melalui kegiatan pengajian rutinan ilmu Nabwu dan Sharaf. Selain itu, komunitas ini juga melakukan pembekalan remaja tentang sejarah umat Islam dan teladan-teladan utama remaja Islam. Kegiatan lainnya, misalnya kegiatan olahraga panahan yang disisipi dengan pengajian keislaman.

Komunitas KALAM dan REUNY fokus pada kegiatan dakwah bilqalam dalam bentuk pembuatan blog dan bulletin dakwah. Kegiatan dakwah bilqalam masih terbatas dilakukan hal ini mengingat keterbatasan sumber daya, penguasaan keterampilan menulis dan masalah finansial untuk biaya cetak. Solusi alternatif kegiatan dakwah bilqalam ini dilakukan dengan memanfaatkan media internet (media sosial) sebagai media dakwah.

Ketiga, kategori bentuk kegiatan dakwah berdasarkan pemanfaatan media dakwah. Berdasarkan hasil penelitian didapatkan bahwa 13 komunitas dakwah remaja Islam di Pangalengan menggunakan media lisan sebagai media berdakwah. 2 komunitas remaja Islam menggunakan media tulisan cetak sebagai media berdakwah. 11 komunitas remaja Islam menggunakan media sosial sebagai media berdakwah antara lain menggunakan facebook, instagram, blog dan whatapps group. Serta 13 komunitas memiliki program dakwah bilhal dalam bentuk pengabdian dan pemberdayaan masyarakat.

Keempat, kategori bentuk kegiatan dakwah berdasarkan variasi kegiatan berupa seminar, diskusi publik, malam pembinaan, panahan, tafakkur alam, kemah keislaman dan ngaji on the road. Dalam hal ini, setiap komunitas remaja Islam memiliki program eventual yang dilaksanakan secara berkala dengan fokus isu tertentu. Misalnya, komunitas IREMA memiliki program kuliah dhuha dan tabligh sekolah, komunitas KALAM memiliki program DILAN (Diskusi Literasi Kepenulisan), komunitas KOMDAPA memiliki program Resolusi Akhlaq, Komunitas FORSIREMA memiliki program Ngabuburide, Komunitas IRSIF 
Ridwan Rustandi \& Haifa Hanifah

memiliki program Kajian Ibyaa-u Lailati Al-Qadr, komunitas MERAPI memiliki program MATAHARI (Mantapkan Hati Bersama MERAPI), Komunitas MMN memiliki program APRIL MOP, komunitas REUNY memiliki program Kajian Ramadhan dan Mabit, dan lain sebagainya. Selain itu, hampir semua komunitaskomunitas ini melakukan dakwah visual melalui posting digital segala bentuk pelaksanaan kegiatan dakwah dalam bentuk poster, famplet, flyer, dan lain-lain.

Berdasarkan ulasan di atas, peneliti merumuskan bentuk-bentuk kegiatan dakwah komunitas remaja Islam di Pangalengan melalui tabel di bawah ini:

Tabel 2.

Bentuk-bentuk Kegiatan Dakwah Komunitas Remaja Islam di Kecamatan Pangalengan

\begin{tabular}{|c|c|c|c|c|c|}
\hline No & $\begin{array}{l}\text { Nama } \\
\text { Komunitas }\end{array}$ & $\begin{array}{l}\text { Program } \\
\text { Unggulan }\end{array}$ & $\begin{array}{l}\text { Variasi } \\
\text { Kegiatan } \\
\text { Dakwah }\end{array}$ & $\begin{array}{l}\text { Media } \\
\text { Dakwah }\end{array}$ & Sarana Kegiatan \\
\hline 1 & $\begin{array}{l}\text { Ikatan Remaja } \\
\text { Masjid Al-Falah } \\
\text { (IRMAFAL) }\end{array}$ & $\begin{array}{l}\text { Sharing Lintas } \\
\text { Organisasi, } \\
\text { Kajian Rutin } \\
\text { Malam Minggu }\end{array}$ & $\begin{array}{l}\text { Dakwah } \\
\text { billisan dan } \\
\text { bilhal }\end{array}$ & $\begin{array}{l}\text { Memiliki } \\
\text { akun media } \\
\text { sosial } \\
\text { untuk } \\
\text { dakwah }\end{array}$ & $\begin{array}{l}\text { Masjid dan Ruang } \\
\text { Publik }\end{array}$ \\
\hline 2 & $\begin{array}{l}\text { Majelis Remaja } \\
\text { dan Pelajar } \\
\text { Islam } \\
\text { (MERAPI) }\end{array}$ & $\begin{array}{l}\text { Kuliah Online, } \\
\text { Ahad } \\
\text { Bermanfaat, } \\
\text { MATAHARI, } \\
\text { Kaderisasi } \\
\text { MERAPI dalam } \\
\text { bentuk MAGMA } \\
\text { (Masa Taaruf } \\
\text { Gerakan } \\
\text { MERAPI) dan } \\
\text { LAHAR } \\
\text { (Latihan Kader } \\
\text { Haroki) }\end{array}$ & $\begin{array}{l}\text { Dakwah } \\
\text { billisan, } \\
\text { bilqalam dan } \\
\text { bilhal }\end{array}$ & $\begin{array}{l}\text { Memiliki } \\
\text { akun media } \\
\text { sosial } \\
\text { untuk } \\
\text { dakwah }\end{array}$ & $\begin{array}{l}\text { Masjid, } \\
\text { Sekolah/Madrasah, } \\
\text { Ruang Publik }\end{array}$ \\
\hline 3 & $\begin{array}{l}\text { Malam Minggu } \\
\text { Ngaji (MMN) }\end{array}$ & $\begin{array}{l}\text { APRIL MOP, } \\
\text { Kajian Rutinan } \\
\text { Malam Minggu }\end{array}$ & $\begin{array}{l}\text { Dakwah } \\
\text { billisan }\end{array}$ & $\begin{array}{l}\text { Memiliki } \\
\text { akun media } \\
\text { sosial } \\
\text { untuk } \\
\text { dakwah }\end{array}$ & Ruang Publik \\
\hline 4 & $\begin{array}{l}\text { Hammock } \\
\text { Tafakkur }\end{array}$ & $\begin{array}{l}\text { Ekspedisi } \\
\text { Dakwah, } \\
\text { Hammockan } \\
\text { Ngaji }\end{array}$ & $\begin{array}{l}\text { Dakwah } \\
\text { billisan dan } \\
\text { bilhal }\end{array}$ & $\begin{array}{l}\text { Memiliki } \\
\text { akun media } \\
\text { sosial } \\
\text { untuk } \\
\text { dakwah }\end{array}$ & Wahana Wisata \\
\hline
\end{tabular}

Sumber : Observasi 2019 
Tabel 2.

Bentuk-bentuk Kegiatan Dakwah Komunitas Remaja Islam di Kecamatan Pangalengan

\begin{tabular}{|c|c|c|c|c|c|}
\hline 5 & $\begin{array}{l}\text { Komunitas } \\
\text { Dakwah } \\
\text { Pangalengan } \\
\text { (KOMDAPA) }\end{array}$ & $\begin{array}{l}\text { RESOLUSI } \\
\text { AKHLAQ }\end{array}$ & $\begin{array}{l}\text { Dakwah } \\
\text { billisan }\end{array}$ & $\begin{array}{l}\text { Memiliki } \\
\text { akun media } \\
\text { sosial untuk } \\
\text { dakwah }\end{array}$ & Ruang Publik \\
\hline 6 & $\begin{array}{l}\text { Bobotoh Taqwa } \\
\text { Pangalengan }\end{array}$ & $\begin{array}{l}\text { Nonto Bareng } \\
\text { dan Ngaji }\end{array}$ & $\begin{array}{l}\text { Dakwah } \\
\text { billisan }\end{array}$ & & Ruang Publik \\
\hline 7 & $\begin{array}{l}\text { Remaja Ukhuwah } \\
\text { Nurul Yaqin } \\
\text { (REUNY) }\end{array}$ & $\begin{array}{l}\text { Kajian Tauhid, } \\
\text { Keorganisasian, } \\
\text { Kaderisasi, Ilmu } \\
\text { Nahwu Shorof, } \\
\text { Ilmu Mustholah } \\
\text { Hadits }\end{array}$ & $\begin{array}{l}\text { Dakwah } \\
\text { billisan, } \\
\text { bilqalam dan } \\
\text { bilhal }\end{array}$ & $\begin{array}{l}\text { Memiliki } \\
\text { akun media } \\
\text { sosial untuk } \\
\text { dakwah }\end{array}$ & $\begin{array}{l}\text { Masjid dan } \\
\text { Ruang Publik }\end{array}$ \\
\hline 8 & $\begin{array}{l}\text { Ikatan Remaja } \\
\text { Studi Islam } \\
\text { Intensif (IRSIF) }\end{array}$ & $\begin{array}{l}\text { Majelis Malam } \\
\text { Rabu } \\
\text { (MAMARA), } \\
\text { Majelis } \\
\text { Tarbiyatunnisa } \\
\text { (MATAN), } \\
\text { Kuliah Shubuh, } \\
\text { Pesantren } \\
\text { Ramadhan, } \\
\text { Latihan Panahan }\end{array}$ & $\begin{array}{l}\text { Dakwah } \\
\text { billisan, dan } \\
\text { bilhal }\end{array}$ & $\begin{array}{l}\text { Memiliki } \\
\text { akun media } \\
\text { sosial untuk } \\
\text { dakwah }\end{array}$ & $\begin{array}{l}\text { Masjid dan } \\
\text { Ruang Publik }\end{array}$ \\
\hline 9 & $\begin{array}{l}\text { Forum Remaja } \\
\text { Islam Ishlahul } \\
\text { Amanah (FRIIA) }\end{array}$ & $\begin{array}{l}\text { Tadarus Rutinan, } \\
\text { Kuliah Shubuh, } \\
\text { Pesantren } \\
\text { Ramadhan }\end{array}$ & $\begin{array}{l}\text { Dakwah } \\
\text { billisan }\end{array}$ & & $\begin{array}{l}\text { Masjid } \\
\text { Sekolah dan } \\
\text { Ruang Publik }\end{array}$ \\
\hline 10 & $\begin{array}{l}\text { Klub Aksara } \\
\text { Literasi Isla, } \\
\text { Ishlahul Amanah } \\
\text { (KALAM) }\end{array}$ & $\begin{array}{l}\text { Diskusi Literasi } \\
\text { Kepenulisan } \\
\text { (DILAN) }\end{array}$ & $\begin{array}{l}\text { Dakwah } \\
\text { billisan dan } \\
\text { bilqalam }\end{array}$ & $\begin{array}{l}\text { Memiliki } \\
\text { akun media } \\
\text { sosial untuk } \\
\text { dakwah }\end{array}$ & Ruang Publik \\
\hline 11 & $\begin{array}{l}\text { Ikatan Remaja } \\
\text { Masjid Al- } \\
\text { Muthmainnah } \\
\text { (IREMA) SMAN } \\
1 \text { Pangalengan }\end{array}$ & $\begin{array}{l}\text { Tadarus Dhuha, } \\
\text { Kultum Am }\end{array}$ & $\begin{array}{l}\text { Dakwah } \\
\text { billisan }\end{array}$ & $\begin{array}{l}\text { Memiliki } \\
\text { akun media } \\
\text { sosial untuk } \\
\text { dakwah }\end{array}$ & $\begin{array}{l}\text { Masjid } \\
\text { Sekolah }\end{array}$ \\
\hline
\end{tabular}

Sumber : Observasi 2019 
Ridwan Rustandi \& Haifa Hanifah

Tabel 2.

Bentuk-bentuk Kegiatan Dakwah Komunitas Remaja Islam di Kecamatan Pangalengan

\begin{tabular}{|c|c|c|c|c|c|}
\hline 12 & $\begin{array}{l}\text { Forum } \\
\text { Silaturahmi } \\
\text { Remaja Masjid } \\
\text { Al-Muttaqin } \\
\text { (FORSIREMA) }\end{array}$ & $\begin{array}{l}\text { Kajian Senin } \\
\text { Malam } \\
\text { (KASIMA), } \\
\text { Yaumul Mar'ah, } \\
\text { Kajian Bulanan } \\
\text { Forsirema } \\
\text { (KABORMA), } \\
\text { Ngabuburide } \\
\text { With Forsirema }\end{array}$ & $\begin{array}{l}\text { Dakwah } \\
\text { billisan dan } \\
\text { bilhal }\end{array}$ & $\begin{array}{l}\text { Memiliki } \\
\text { akun media } \\
\text { sosial untuk } \\
\text { dakwah }\end{array}$ & $\begin{array}{l}\text { Masjid dan } \\
\text { Ruang Publik }\end{array}$ \\
\hline 13 & $\begin{array}{l}\text { Syubbanul } \\
\text { Firdaus }\end{array}$ & Kajian Keislaman & $\begin{array}{l}\text { Dakwah } \\
\text { billisan dan } \\
\text { bilhal }\end{array}$ & $\begin{array}{l}\text { Memiliki } \\
\text { akun media } \\
\text { sosial untuk } \\
\text { dakwah }\end{array}$ & $\begin{array}{l}\text { Masjid } \\
\text { Sekolah dan } \\
\text { Ruang Publik }\end{array}$ \\
\hline
\end{tabular}

Sumber : Observasi 2019

Tabel 2. di atas menunjukkan bagaimana variasi bentuk kegiatan dakwah yang dilakukan oleh komunitas remaja Islam di Pangalengan. Pada hakikatnya, setiap komunitas dakwah tersebut melakukan proses kegiatan dakwah dengan terlebih dahulu melakukan pengkajian dan pemetaan terhadap kebutuhan objek dakwah. Sehingga, rangkaian kegiatan dakwah dirumuskan secara terencana, terukur dan terarah. Proses perencanaan ini terbukti dengan adanya ragam kegiatan dakwah yang dilaksanakan secara variatif dan kreatif. Sehingga, para penggerak komunitas dakwah remaja di Pangalengan dituntut untuk bisa membaca dan memetakan problematika dakwah remaja di Pangalengan. Selain itu, setiap komunitas remaja Islam di Pangalengan berupaya melakukan proses pembinaan, pengamalan dan pengajaran nilai-nilai ajaran Islam agar para remaja di Pangalengan secara keseluruhan menjadi objek atau sasaran dakwah yang diharapkan mampu melakukan pembinaan dalam aspek akhlaq dan moral serta membentengi aqidah para remaja dari berbagai tantangan global yang datang baik dari internal umat Islam maupun dari aspek eksternal seperti kristenisasi dan kecanggihan teknologi.

Penggunaan sarana publik (selain masjid) sebagai tempat pelaksanaan kegiatan dakwah merupakan bentuk kepekaan dan ketangkasan para penggerak komunitas dakwah remaja di Pangalengan agar semakin dekat dengan objek dakwah. Penggunaan sarana publik seperti terminal, wahana wisata, sekolah dan fasilitas keramaian lainnya menjadi salah satu strategi atau pendekatan subjek dakwah (komunitas) dengan objek dakwah (remaja). Hal ini mengindikasikan ada variasi strategi dan bentuk kegiatan dakwah yang disesuaikan dengan kebutuhan, minat dan trend yang berkembang di kalangan remaja di Pangalengan. Selanjutnya, 
hampir sebagian besar komunitas remaja Islam di Pangalengan memanfaatkan media internet sebagai media dakwah. Variasi konten yang dihasilkan dalam media internet tersebut baik dalam bentuk poster, video dan bulletin dakwah secara digital.

Dakwah sebagai kewajiban yang harus dilaksanakan oleh umat Islam merupakan ikhtiar dan usaha yang tidak mengenal henti. Di sisi lain, dakwah juga berhadapan dengan masyarakat yang dinamis dan terus berubah, sejalan dengan perkembangan teknologi komunikasi, dan peradaban umat manusia yang terus melaju pesat. Oleh karena itu, penggunaan media internet sebagai media dakwah di era cyber ini merupakan sesuatu yang penting dan mutlak, melengkapi mediamedia lainnya yang telah digunakan selama in (Muahemin, 2017: 346). Penggunaan internet sebagai media dakwah oleh komunitas remaja Islam di Pangalengan menunjukkan proses dan usaha para juru dakwah dalam menguasai media baru seperti internet untuk kelangsungan dakwah. Tentunya, hal ini didukung dengan adanya upaya penguasaan terhadap keterampilan dakwah kreatif berbasis digital. Dengan begitu, proses pelaksanaan dakwah komunitas remaja Islam di Pangalengan senantiasa berupaya agar sesuai dengan trend yang berkembang di kalangan remaja. Terutama trend yang dengan mudah menyebar melalui teknologi internet. Dakwah di era digital menghendaki adanya kreativitas dan inovasi dari pada da'i agar wujud Islam Rahmatan Lil Alamin senantiasa berselaras dengan kemajuan zaman.

\section{PENUTUP}

Penelitian ini berupaya menganalisis dinamika dakwah yang terjadi di Pangalengan yang dilakukan oleh komunitas remaja Islam. Berdasarkan pengamatan peneliti, pemilihan 13 komunitas remaja Islam di Pangalengan ini dianggap sebagai representasi gerakan dakwah remaja yang memiliki konsep dan pola gerakan yang jelas. Hal ini dapat dilihat dari mulai proses perencanaan dan pembacaan segmentasi madh'u, proses penetapan tujuan dan target dakwah sampai dengan proses pelaksanaan kegiatan dakwah dala bentuk-bentuk kegiatan yang variatif dan kreatif.

Eksistensi komunitas remaja Islam di Pangalengan harus terus dirawat bahkan dikembangkan dengan lebih baik lagi. Mengingat bahwa problematika remaja di Pangalengan membutuhkan solusi agar proses pembinaan mental dan penanaman nilai-nilai keislaman menjadi fondasi bagi moralitas remaja. Selain itu, jumlah remaja usia sekolah (setingkat SMP dan SMA) di Pangalengan sekitar 11.414 orang merupakan jumlah target dakwah yang besar. Dalam hal ini, seluruh stakeholders di kecamatan Pangalengan harus berkolaborasi membangun kekuatan bersama dari mulai pemerintah kecamatan, pemerintah desa, pengurus RW dan RT, para tokoh masyarakat, para tokoh pemuda dan organisasi-organisasi keislaman untuk menjawab permasalahan-permasalahan moralitas remaja di 
Ridwan Rustandi \& Haifa Hanifah

Pangalengan, terutama dalam aspek keagamaan. Tantangan dakwah di kalangan remaja semakin kompleks di tengah berbagai tantangan dan ancaman globalisasi. Hal itu terutama di era konvergensi media yang semakin memudahkan akses komunikasi dan informasi. Apalagi, usia remaja adalah masa peralihan dengan ciri adanya ketegangan jiwa, ketidakstabilan emosi, penegasan identitas dan jati diri dan masa peralihan menuju kematangan mental dan fisik. Kehadiran komunitas remaja Islam di Pangalengan dapat dipandang sebagai salah satu jawaban akan pentingnya membangun komunitas positif di kalangan remaja.

\section{DAFTAR PUSTAKA}

Al-Amin, M., \& Juniati, D. (2017). Klasifikasi Kelompok Umur Manusia Berdasarkan Analisis Dimensi Fraktal Box Counting dari Citra Wajah dengan Deteksi Tepi Canny, MATHunesa: Jurnal Ilmiah Matematika, 2(6), 3342.

https://jurnalmahasiswa.unesa.ac.id/index.php/mathunesa/issue/view/1 271

Aripudin, A., \& Sambas, S. (2012). Dakwah Damai: Pengantar Dakwah Antarbudaya. Bandung: Remaja Rosdakarya.

Aziz, A. M. (2009). Ilmu Dakwah. Jakarta: Kencana Pranada Media Group.

Badan Pusat Statistik (BPS) Kabupaten Bandung, 2018, Kabupaten Bandung dalam Angka.

Badan Pusat Statistik (BPS) Kabupaten Bandung, 2018, Kecamatan Pangalengan dalam Angka.

Ginda. (2018). Dinamika Dakwah Islam dalam Perspektif Managemen Perubahan di Kecamatan Tampan, Jurnal Masyarakat Madani, 3(2), 12-32. http://ejournal.uin-suska.ac.id/index.php/jmm/issue/view/520

Haryanto, S. (2015). Sosiologi Agama Dari Klasik Hingga Postmodern, Yogyakarta: Arruzz Media.

Khoiruddin. (2012). Aktualisasi Dakwah dalam Perspektif Transformasi Sosial, Al-Mishbah, $\quad 8(1) . \quad$ https://almishbahjurnal.com/index.php/almishbah/issue/view/1

Muhyiddin, A. dkk. (2014) Dakwah Perspektif al-Quran, Kajian Dakwah Multiperspektif: Teori, Metodologi, Problem, dan Aplikasi. Bandung: Remaja Rosdakarya.

Nawawi, A. (2017). Motivasi Terhadap Tingkahlaku dalam Proses Dakwah, Komunika, 1(2). DOI 10.24090/komunika.v1i2.792

Nawawi, A. (2018). Pengajian Remaja dan Kontribusinya Dalam Pembentukan Akhlak Generasi Muda di Bulak Setro Surabaya, dalam Syaikhuna, 9(1). http://ejournal.kopertais4.or.id/madura/index.php/syaikhuna/issue/view $/ 746$

Nurjanah, T., \& Fatoni, U. (2019). Dakwah Kelompok dalam Komunitas Pejuang 
Mahar, ANIDA (Aktualisasi Nuansa Ilmu Dakwah), 19(1), 34-49. DOI: https://doi.org/10.15575/anida.v19i1.5041

Putrawan, A.D. (2018). Sekolah Perjumpaan sebagai Gerakan Dakwah Berbasis

Komunitas, Lentera, 2(2), 2017-221. DOI: https://doi.org/10.21093/lentera.v2i2.1267

Rachmiatie, A., Sidik, A.A., \& Farihat. (2004). Proses Sosialisasi Informasi Agama

Islam melalui Media Komunitas sebagai Pembentuk Moralitas Remaja Muslim, Mimbar, 23(1), 121-156. https://ejournal.unisba.ac.id/index.php/mimbar/issue/view/36

Rustandi, R., \& Sahidin, S. (2019). Analisis Historis Manajemen Dakwah Rosulullah Saw dalam Piagam Madinah, dalam Tamaddun: Jurnal Sejarah dan Kebudayaan Islam, 7(2), 362-387. DOI: 10.24235/tamaddun.v7i2.5503

Rustandi, R. (2019). Cyberdakwah: Internet sebagai Media Baru dalam Sistem Komunikasi Dakwah Islam, dalam NALAR: Jurnal Peradaban dan Pemikiran Islam, 3(2), 84-95.

Sherkat, D. E. (2006). Politics and Social Movements. Helen Rose Ebaugh (ed.). Handbook of Religion and Social Institutions. New York: Springer.

Soekanto, S. (2013). Sosiologi Suatu Pengantar, Jakarta: Rajawali Press.

Susanto, D. (2014). Pola Strategi Dakwah Komunitas Habaib di Kampung Melayu Semarang, Dimas, 14(1), 159-185. http://journal.walisongo.ac.id/index.php/dimas/issue/view/88

Syukur, A. (2014). Dinamika Dakwah Dalam Komunikasi dan Penyiaran Islam; Pendekatan Historisasi, Formulasi dan Aplikasi, dalam Bina Al-Ummah, 9(2). Thamrin, H. et.all. (2003). Peta Dakwah Kota Pekanbaru, Kekuatan, Kelemahan, Peluang dan Ancaman. Balitbang MUI.

Zaini, A. (2017). Dakwah dan Pemberdayaan Masyarakat Perdesaan, Jurnal Ilmu Dakwah, 37(2), 284-301.

http://journal.walisongo.ac.id/index.php/dakwah/issue/view/293 
Ridwan Rustandi \& Haifa Hanifah 